\title{
Review of the Traditional Uses, Phytochemistry, and Pharmacological Activities of Rhoicissus Species (Vitaceae)
}

\author{
Nondumiso P. Dube ${ }^{1}$, Xavier Siwe-Noundou ${ }^{2, *}$, Rui W. M. Krause ${ }^{2}{ }^{\circledR}$, Douglas Kemboi ${ }^{1}($, \\ Vuyelwa Jacqueline Tembu ${ }^{1, *}$ and Amanda-Lee Manicum ${ }^{1, *}$ \\ 1 Department of Chemistry, Tshwane University of Technology, 175 Nelson Mandela Drive, Private Bag X680, \\ Pretoria 0001, South Africa; DlaminiNP2@tut.ac.za (N.P.D.); kemboidouglas01@gmail.com (D.K.) \\ 2 Department of Chemistry, Rhodes University, P.O. Box 94, Grahamstown 6140, South Africa; \\ r.krause@ru.ac.za \\ * Correspondence: X.siwenoundou@ru.ac.za (X.S.-N.); TembuVJ@tut.ac.za (V.J.T.); \\ ManicumAE@tut.ac.za (A.-L.M.); Tel.: +27-(012)-382-6309 (A.-L.M.)
}

check for updates

Citation: Dube, N.P.; Siwe-Noundou, X.; Krause, R.W.M.; Kemboi, D.; Tembu, V.J.; Manicum, A.-L. Review of the Traditional Uses, Phytochemistry, and Pharmacological Activities of Rhoicissus Species (Vitaceae). Molecules 2021, 26, 2306. https://doi.org/ $10.3390 /$ molecules 26082306

Academic Editors: Deok-Chun Yang, Farid Chemat, Lorenzo Di Cesare Mannelli and Ramya Mathiyalagan

Received: 18 February 2021

Accepted: 25 March 2021

Published: 16 April 2021

Publisher's Note: MDPI stays neutral with regard to jurisdictional claims in published maps and institutional affiliations.

Copyright: (c) 2021 by the authors. Licensee MDPI, Basel, Switzerland. This article is an open access article distributed under the terms and conditions of the Creative Commons Attribution (CC BY) license (https:// creativecommons.org/licenses/by/ $4.0 /)$.

\begin{abstract}
Species within the genus Rhoicissus (Vitaceae) are commonly used in South African traditional medicine. The current review discusses the occurrence, distribution, traditional uses, phytochemistry, and pharmacological properties of Rhoicissus species covering the period 1981-2020. The data reported were systematically collected, read, and analysed from scientific electronic databases including Scopus, Scifinder, Pubmed, and Google Scholar. Reported evidence indicates that species in this genus are used for the treatment of gastrointestinal complaints, sexually transmitted infections (STIs), and infertility, as well as to tone the uterus during pregnancy and to facilitate delivery. Pharmacological studies have further shown that members of the Rhoicissus genus display antidiabetic, uterotonic, ascaricidal, hepatoprotective, antioxidant, antimicrobial, anticancer, and anti-inflammatory properties. They are linked to the presence of bioactive compounds isolated from the genus. Hence, Rhoicissus species can potentially be an alternative therapeutic strategy to treat diseases and develop safer and more potent drugs to combat diseases. Plant species of this genus have valuable medicinal benefits due to their significant pharmacological potential. However, scientific investigation and information of the therapeutic potential of Rhoicissus remain limited as most of the species in the genus have not been fully exploited. Therefore, there is a need for further investigations to exploit the therapeutic potential of the genus Rhoicissus. Future studies should evaluate the phytochemical, pharmacological, and toxicological activities, as well as the mode of action, of Rhoicissus crude extracts and secondary compounds isolated from the species.
\end{abstract}

Keywords: botany; cuneifolia; pharmacology; phytochemistry; Rhoicissus; Vitaceae

\section{Introduction}

For centuries, herbal medicines have been used worldwide to treat and prevent various ailments, particularly in developing countries where infectious diseases are endemic [1-3]. The World Health Organization estimates that approximately $80 \%$ of the world population uses traditional treatment methods for their primary healthcare system [4-6]. This is due to the increasing costs of conventional treatments, difficult access to modern health facilities, exhaustion of conventional therapies, lack of effective drugs for a serious illness, evolution of multidrug-resistant microorganisms, belief that natural products are better or safer, and cultural or spiritual preference [1,4-8]. This has drawn scientific and research interest toward naturally derived compounds. These are considered safe, effective, affordable, and biologically friendly, having fewer toxic side-effects than synthetic drugs [2,9-11]. Furthermore, the interest in natural products has yielded numerous impressive results, including the discovery of diversely sourced products with antimicrobial, anti-inflammatory, antihelminthic, antidiabetic, and anticancer activity, leading to pharmaceutical companies' 
acceptance of natural products as a part of the modern and effective tools for new drugs and new drug leads $[11,12]$.

Traditionally, Rhoicissus species are mainly used to enhance fertility and to facilitate delivery during pregnancy. Decoctions are taken orally to treat impotence and infertility. Women take them in the last trimester of pregnancy to ensure the good health of the mother and fetus by preventing long and complicated labour [13-15]. Species from this genus are also used for the treatment of cattle disease, gastrointestinal complaints, and cuts, swollen glands through warming of the roots in fire and pressing them against the glands, diarrhoea, broken bones, cuts, epilepsy, menorrhagia, renal complaints, sprained ankles, stomach ailments, and sores, in addition to as an antiemetic in children and as a general pain reliever [14,16-19].

The species from the genus Rhoicissus have also been reported to contain numerous secondary metabolites such as alkaloids, terpenoids, and flavonoids which display various biological effects such as anti-inflammatory, anticancer, and antioxidant activities [14]. Phytochemical investigations of Rhoicissus species have revealed the presence of bioactive compounds responsible for these activities. As a successful example, proanthocyanidin monomers and dimers, as well as gallic acid, isolated from Rhoicissus tridentata were found to stimulate smooth muscle contraction in isolated rat uterine tissue [15]. Lupenone isolated from Rhoicissus species has also been reported to possess antibiotic and antioxidant activity [15]. However, despite the medicinal application of this genus and the bioactive compounds isolated and identified from them, there exists no consolidation on previous and latest scientific information on the phytochemistry and biological activities of genus Rhoicissus. Hence, the current report presents a comprehensive literature review from 1981 to 2020. It includes the botany, geographical distribution, traditional uses, phytochemistry, and pharmacological properties of Rhoicissus species.

\section{Literature Survey Databases}

The data reported were systematically collected, read, and analysed from scientific electronic databases including Scopus, Elsevier, Scifinder, Research gate, ScienceDirect, and Google Scholar. Keywords such as Vitaceae, Rhoicissus, and traditional use were submitted during the search. Additional information on the botany, geographical distribution, traditional uses, phytochemistry, and pharmacological properties of Rhoicissus species was gathered from references in journal articles, book chapters, books, journal articles, and encyclopedias. The information thus obtained was critically analysed to obtain new insights and possible knowledge gaps for future research opportunities about Rhoicissus species.

\section{Family Vitaceae}

Vitaceae, also known as the grape family, are a medium-sized plant family with about 950 species belonging to 16 genera primarily distributed in the tropics, subtropics, and the north and south temperate zones [20-25]. It is reported that Vitaceae have a largely pantropical distribution in Asia, Africa, Australia, the neotropics, and the Pacific islands, with only a few genera in temperate regions $[23,26,27]$. The family is well known for containing one of the most economically important fruit crops, the grape (Vitis vinifera L.), as the source of wine, sultanas, currants, and raisins [24,26].

This known group of flowering plants usually features erect, prostrate, woody climbers, often with swollen or jointed nodes and herbaceous vines, or small succulent trees [21,24,28,29]. Vitaceae are readily distinguished from other angiosperm families by their unique seed morphology, inflorescences as cyme, corymb, or panicle, and leaf-opposed tendrils, enabling the family to be the most successful climbers in tropical and temperate forests $[23,25,29,30]$. The stomata apertures in the epidermis are bounded by two guard cells which primarily allow the rapid movement of carbon dioxide, water vapour, and oxygen in and out of the leaf [29]. The flowers are small, greenish, and inconspicuous, with a ring-like or lobed disc $[28,31]$. 
According to the phylogenic and morphological evidence, the new classification places the 950 species and 16 genera into five tribes: (i) tribe Ampelopsideae J. Wen \& Z. L. Nie, trib. nov. (47 species in four genera: Ampelopsis, Nekemias, Rhoicissus, and Clematicissus); (ii) tribe Cisseae Rchb. (300 species in one genus: Cissus); (iii) tribe Cayratiaea J. Wen \& L. M. Lu, trib. nov. (370 species in seven genera: Cayratia, Causonis, Afrocayratia, Pseudocayratia, Acareosperma, Cyphostemma, and Tetrastigma); (iv) tribe Parthenocisseae J. Wen \& Z. D. Chen, trib. nov (16 species in two genera: Parthenocissus and Yua); (v) tribe Viteae Dumort (190 species in two genera: Ampelocissus and Vitis). The largest genera in this family are Cissus L. and Cyphostemma (Planch) [23,25,26,30]. A taxonomy of the Vitaceae family is summarised in Table 1.

Table 1. Taxonomy of the Vitaceae family.

\begin{tabular}{ccc}
\hline Taxonomic Hierarchy & Classification & Reference \\
\hline Kingdom & Plantae-plants & {$[23,25,26,30]$} \\
Subkingdom & Tracheobionta-vascular plants & {$[23,25,26,30]$} \\
Super division & Spermatophyta-seed plants & {$[23,25,26,30]$} \\
Division & Magnoliophyta-flowering plants & {$[23,25,26,30]$} \\
Class & Magnoliopsida-dicotyledons & {$[23,25,26,30]$} \\
Subclass & Rosidae & {$[23,25,26,30]$} \\
Order & Rhamnales & {$[23,25,26,30]$} \\
Family & Vitaceae-grape family & {$[23,25,26,30]$} \\
\hline
\end{tabular}

\section{Genus Rhoicissus}

\subsection{Occurance, Distribution, and Botanical Description}

The genus Rhoicissus Planch. is one of the smallest genera in the family [26]. Approximately 12 species represent it, namely, Rhoicissus tridentata, $R$. digitata, $R$. rhomboidea, $R$. tomentosa, $R$. revoilli, $R$. sessilifolia, $R$. microphylla, $R$. kougabergensis, $R$. laetans, $R$. capensis, $R$. erythrodes, and $R$. sekhukhuniensis, which are endemic to tropical and southern Africa [26,27,32]. Rhoicissus species are distributed in the Afrotropical zone of Africa, to the south of the Sahara Desert, in the southern and eastern parts of the Arabian Peninsula, Madagascar, southwestern Pakistan, and the Islands of the Western Indian Ocean [26,30].

Rhoicissus species are described as climbing shrubs or woody vines, with tendrils opposite the leaves and more or less swollen nodes. The leaves are different, simple, or palmately compound. They are often rusty, with inflorescences borne opposite the leaves with 5-7 merous flowers that are small, greenish, and inconspicuous, with a ring-like or lobed disc. The stamens are equal in number to the petals and opposite to them [31,32]. The flower buds are globose in outline, while the floral disc is annular, entire, and thick [33]. Furthermore, they usually have 5-6 fleshy petals per flower. The genus can be distinguished from other genera of the tribe by its distinctly rugose seeds with linear chalaza and divergent ventral in folds [25]. The summary of phytochemistry, ethnomedicinal and biological studies reported for Rhoicissus species is illustrated in Table 2.

Table 2. Summary of phytochemistry, ethnomedicinal, and biological studies reported for Rhoicissus species.

\begin{tabular}{ccccc}
\hline Plant Name & Botanical Description & Traditional Uses & $\begin{array}{c}\text { Biological } \\
\text { Activity }\end{array}$ & Phytochemistry \\
\hline R. capensis & Not reported & Not reported & Not evaluated & Not evaluated \\
\hline R. digitata & Reported & Reported & Evaluated & Evaluated \\
\hline R. erythrodes & Not reported & Not reported & Not evaluated & Not evaluated \\
\hline R. kougabergensis & Not reported & Not reported & Not evaluated & Not evaluated \\
\hline R. laetans & Reported & Not reported & Not evaluated & Not evaluated \\
\hline
\end{tabular}


Table 2. Cont.

\begin{tabular}{|c|c|c|c|c|}
\hline Plant Name & Botanical Description & Traditional Uses & $\begin{array}{c}\text { Biological } \\
\text { Activity }\end{array}$ & Phytochemistry \\
\hline R. microphylla & Reported & Not reported & Not evaluated & Not evaluated \\
\hline R. revoilli & Reported & Reported & Evaluated & Evaluated \\
\hline R. rhomboidea & Reported & Reported & Evaluated & Not evaluated \\
\hline R. sekhukhuniensis & Not reported & Not reported & Not evaluated & Not evaluated \\
\hline R. sessilifolia & Not reported & Not reported & Not evaluated & Not evaluated \\
\hline R. tomentosa & Reported & Reported & Evaluated & Evaluated \\
\hline R. tridentata & Reported & Reported & Evaluated & Evaluated \\
\hline
\end{tabular}

\subsection{Rhoicissus digitata}

Rhoicissus digitata (L.f.) Gilg \& Brandt can grow and reach $15 \mathrm{~m}$ in length, is usually found in riparian fringing vegetation, and is reportedly from Natal, Transvaal (South Africa) and Mozambique [34]. This species is a vigorous, evergreen vine, climbing by leaf-opposed tendrils. Leaves are compound, usually trifoliate, although palmate compound leaves with four or five leaflets are not uncommon. Tendrils and axillary buds are present at every node and unbranched. Inflorescences are leaf-opposed and cymose, with sparsely compound dichasia on which a small number of flowers are produced. Fruits form in small clusters; they are green when unripe and turn dark purple when ripe, and they ripen from September through to December (Figure 1A) [34,35]. It is well known as baboon grape and dune grape (in English), isinwazi (in isiZulu), and vyfvingerdruif (in Afrikaans), and they are used for medicinal purposes [35].
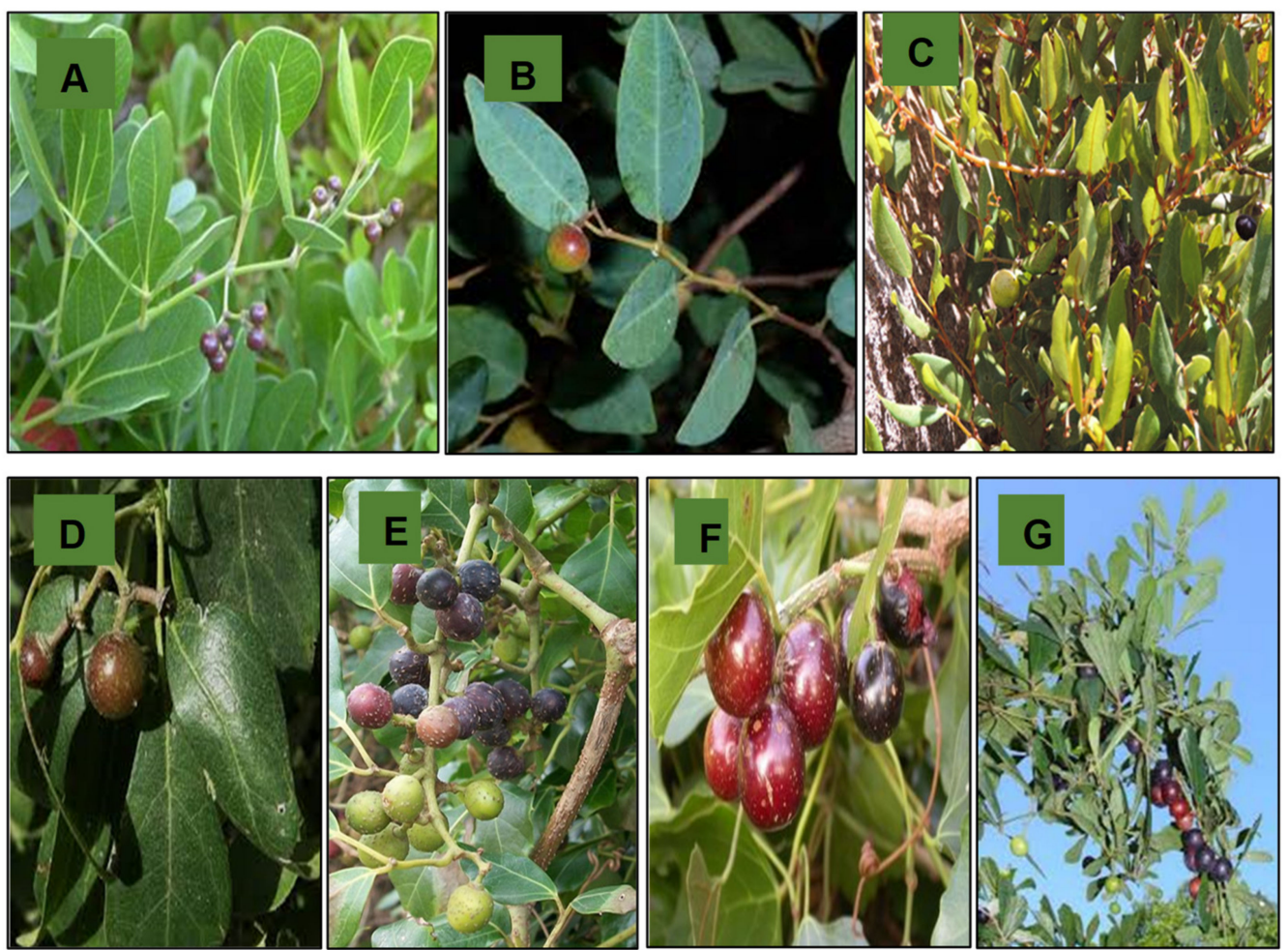

Figure 1. Rhoicissus species: (A) R. digitata; (B) R. laetans; (C) R. microphylla; (D) R. revoilii; (E) R. rhomboidea; (F) R. tomentosa; (G) R. tridentata. 


\subsection{Rhoicissus laetans}

Rhoicissus laetans (Turcz.) Gilg \& Brandt is a shrub up to $1.5 \mathrm{~m}$ high, sometimes scrambling with simple, petiolate leaves and absent tendrils [33]. Its berries are $12 \mathrm{~mm}$ in diameter. Classification of this species in the genus Rhoicissus is supported by the shape of its flower buds, structure of the floral disc, and inflorescence morphology [33]. R. laetans is distinguished from all the other members of the genus by its shrubby habit and simple, glabrous, glaucous green leaves (Figure 1B) [33]. R. laetans is endemic to the northeastern Transvaal escarpment, where it occurs in a small area. The species is found in mountain grassland with stunted shrub vegetation or steep, densely wooded kloof slopes with mixed bushveld vegetation. Occasionally, it occurs in riverine forest. The species grows on soils derived from quartzite and sandstone, and it flowers from at least November till February [33].

\subsection{Rhoicissus microphylla}

Rhoicissus microphylla (Turcz.) Gilg \& Brandt is a small shrub which has ovate leaves with the lamina's undersurface covered with reddish-brown hairs (Figure 1C). It occurs in the Eastern Cape, South Africa [33].

\subsection{Rhoicissus revoilii}

Rhoicissus revoilii Planch., commonly known as bushveld grape or warty grape, is a woody climber with tendrils about $1-10 \mathrm{~m}$ in height [18]. It is a shrub, robust woody climber, or a creeper in mid- to high-altitude forests, forest margins, bushveld, riverine shrubs, or woodlands [36]. This species has glossy dark green trifoliate leaves with entire margins, looping lateral veins, and domatia on lateral vein axils of the abaxial surface (Figure 1D). The leaflets are elliptic, and the laterals of this species are asymmetrical, glabrous, or hairy [36]. Their fruits are reddish to black, two-lobed, round in shape and edible [31]. It is distributed in eastern Africa from Ethiopia and Sudan to the Democratic Republic of Congo, Zambia, Zimbabwe, Mozambique, and eastern South Africa (Transvaal, Natal, Swaziland), as well as in Ghana, Comoro Islands, Saudi Arabia, and Yemen [37].

\subsection{Rhoicissus rhomboidea}

Rhoicissus rhomboidea (E. Mey. ex Harv.) Planch. is a canopy climber that can grow and reach $20 \mathrm{~m}$ [36]. It is usually referred to as bastard forest grape or rope wood grape and is distributed in Eastern South Africa (Transvaal, Natal, Swaziland, Cape Province), Mozambique [37]. This species is found in forests, forest margins, and thickets. The leaves are always made up of rhomboid leaflets (asymmetrical rhomboid for lateral leaflets) and almost always with six dentitions along the margin. It has a globose bud shape with thick spreading petals. The leaflets are shortly stalked, $1-4 \mathrm{~mm}$ long. It has trifoliate leaves and russet hairs on both surfaces of the leaflets. The leaves are leathery, glossy, and dark green on the adaxial surface and without hair when fully grown (Figure 1E) [36].

\subsection{Rhoicissus tomentosa}

Rhoicissus tomentosa (Lam.) Wild \& Drummond is commonly known as an evergreen grape in English, idiliya in Xhosa, and isiNwazi in Zulu, and it is distributed in southern Africa (Transvaal, Natal, Swaziland, Cape Province) [37]. R. tomentosa can either be a scrambling shrub or a canopy climber that can reach up to $20 \mathrm{~m}$ in height. It is found on the fringes of forests or gaps in closed forests and on riverine bushes [36]. The leaves of $R$. tomentosa are broadly transversely elliptic to reniform [33]. The leaves have lobes along the margin, simple in form, and three-nerved at the base. They are dark green on the adaxial surface and covered with rusty velvet hairs on the abaxial surface (Figure 1F). Rusty velvety hairs are also found covering young stems and tendrils but are later lost on stems as they mature and are replaced by raised dots known as lenticels [36]. Their flowers in dense axillary heads are small and yellowish-green. The fruit is edible, globose, about $20 \mathrm{~mm}$ in diameter, and red to purplish-black [31]. 


\subsection{Rhoicissus tridentata}

Rhoicissus tridentata is a polymorphic species with numerous nomenclature revisions over the last two centuries [38]. Originally, this species was divided and classified as several species in the genus Rhus. It was later reclassified in the genus Cissus. Later, Wild and Drummond in 1963 combined three different species, R. cuneifolia, R. erythrodes, and $R$. cirrhiflora and classified them as $R$. tridentata [20]. Urton then combined five different species in 1986, R. cuneifolia, R. erythrodes, R. cirrhiflora, R. pauciflora, and R. dimidiata, and classified them as $R$. tridentata but divided the species into two subspecies, being subspecies tridentata and subspecies cuneifolia $[20,38]$. Cissus dimidiate was noted as being a mere form of Rhoicissus sericea. They considered R. sericea to be conspecific with the plant named Cissus dimidiata by Ecklon and Zeyher, 1835 and correctly applied the name Rhoicissus dimidiata to them [20].

The subspecies are divided according to the number of indentations on the leaflet margins [38]. If the leaflets have no dentations or crenations on the leaflet margins or if the number of dentations is four or less, they are classified as subspecies tridentata. If the leaflet has more than four dentations, then it is classified as cuneifolia. The subspecies cuneifolia is more prevalent, having a wider distribution, extending from the Eastern Cape to the northern portion of South Africa. In contrast, subspecies tridentata occurs from Riversdale district eastward to Port St Johns and then extends inland in the Southeastern Cape to the Karoo of South Africa [20].

R. tridentata (L.f) Wild \& Drumm. subsp. cuneifolia (Eckl. \& Zehr.), N.R. Urton is a deciduous shrubby creeper in the Vitaceae family. It is commonly known as wild grape (English), isinwazi (Zulu), and umnxeba (isiXhosa) [39]. This subspecies occurs in various habitats but is primarily found in forests along forest margins or grows as an erect shrub of up to $2 \mathrm{~m}$ or more in open grassy woodlands [20]. R. tridentata has tendrils and can grow up to $3 \mathrm{~m}$ high, spreading up to $1.5 \mathrm{~m}$. The leaves are trifoliate with wedge-shaped leaflets, each having a serrated margin (Figure 1G). The plant bears small inconspicuous yellowish-green flowers followed by small brownish-red berries [39]. Lignotubers ranging in size from 5 to $30 \mathrm{~cm}$ in diameter are attached to the roots [20].

\section{Ethnomedicinal Uses of Rhoicissus Species}

Species of the Rhoicissus genus are widely used in traditional medicines in African medicinal systems to treat various diseased conditions. According to several reports, they are common medicinal herbs used by the Zulus and Xhosas of South Africa. They are used to treat cattle diseases, high blood pressure and acute headaches, as well as for blood purification and intestinal cleansing, increasing fertility, relieving menstruation pain, managing helminthiasis and venereal diseases, treating bloody constipation, increasing milk production in lactating mothers, wound and ringworm healing, anaesthetic properties, and facilitating delivery during pregnancy, among others [14,40-43], as summarised in Table 3. However, no particular class of compound has been identified or linked to a particular medicinal application. Furthermore, even though most of the Rhoicissus species are used in African traditional medicine, their prescription, mechanisms and mode of actions, associated side-effects, and/or proven efficacy are not clear. A more detailed study is needed to establish their mode of action, side-effects, and safety. 
Table 3. Traditional medicinal uses reported for Rhoicissus species.

\begin{tabular}{|c|c|c|c|c|}
\hline Plant Name & $\begin{array}{c}\text { Ethnic Name } \\
(\mathrm{Z}-\mathrm{Zulu} ; \mathrm{X}-\mathrm{Xhosa})\end{array}$ & Part & Traditional Use & Reference \\
\hline \multirow{5}{*}{ R. digitata } & \multirow{5}{*}{$\begin{array}{l}\text { Isinwazi }(Z) ; \\
\text { Uchititibhunga }(X, Z) ; \\
\text { umNangwazi }(Z) ; \\
\text { umPhambane (Z); } \\
\text { iTangalehlathi }(Z) ; \\
\text { umThwazi }(Z)\end{array}$} & Leaf & $\begin{array}{l}\text { During pregnancy, to facilitate delivery, } \\
\text { isihlambezo and inembe, which is taken as an } \\
\text { abortifacient. }\end{array}$ & [14] \\
\hline & & & It is used to treat cattle diseases. & [40] \\
\hline & & Tubers & $\begin{array}{c}\text { An infusion of the tuber is taken for high blood } \\
\text { pressure and acute headaches; } \\
\text { It is used to treat goats and sheep with } \\
\text { paratyphoid. }\end{array}$ & [41] \\
\hline & & Bulbs & $\begin{array}{l}\text { Enema for blood purification and intestinal } \\
\text { cleansing; } \\
\text { Used to treat gastrointestinal complaints; } \\
\text { Used as an amulet that destroys gossip; } \\
\text { The plant is also used to increase fertility; } \\
\text { Used to treat painful menstruation; } \\
\text { Used as a general pain reliever. }\end{array}$ & {$[42,43]$} \\
\hline & & Roots & Used in the preparation of stomach medicine. & {$[16,44]$} \\
\hline R. rhomboidea & Isinwazi (Z) & Roots & Used during pregnancy to facilitate delivery. & [14] \\
\hline \multirow{5}{*}{ R. tomentosa } & \multirow{5}{*}{$\begin{array}{c}\text { Isinwazi } \\
\text { Idiliya }(X) ; \\
\text { Impindabamshaye }(X) ; \\
\text { UmPhambane }(Z)\end{array}$} & $\begin{array}{l}\text { Leaf/ } \\
\text { stem }\end{array}$ & $\begin{array}{l}\text { Anthelminthic for calves, } \\
\text { during pregnancy to ensure a safe delivery, } \\
\text { and dysmenorrhoea. }\end{array}$ & [14] \\
\hline & & Bark & $\begin{array}{l}\text { Used for heartwater in livestock by crushing } \\
\text { and boiling in water and used with Kedrostis } \\
\text { africana to treat } 3 \text { day stiff sickness. }\end{array}$ & [45] \\
\hline & & \multirow{3}{*}{ Roots } & $\begin{array}{l}\text { Crushed and boiled in milk for young calves to } \\
\text { treat or manage helminthiasis. }\end{array}$ & [45] \\
\hline & & & $\begin{array}{l}\text { The boiled roots fusion are used to enhance } \\
\text { fertility. }\end{array}$ & {$[42,44,46]$} \\
\hline & & & To treat goats and sheep with paratyphoid. & [41] \\
\hline \multirow{6}{*}{ R. revoilii } & \multirow{6}{*}{ Isinwazi (Z) } & \multirow{2}{*}{ Roots } & $\begin{array}{l}\text { A root decoction is taken as a remedy for } \\
\text { venereal diseases and bloody constipation. }\end{array}$ & [18] \\
\hline & & & $\begin{array}{l}\text { Decoctions are given to breastfeeding mothers } \\
\text { and cows to increase milk production. }\end{array}$ & [47] \\
\hline & & Stem & $\begin{array}{c}\text { Sap from the stem is applied to cuts, burns, and } \\
\text { sores. }\end{array}$ & [18] \\
\hline & & \multirow[t]{3}{*}{$\begin{array}{l}\text { Leaves } \\
\text { (crushed) }\end{array}$} & $\begin{array}{l}\text { They are externally rubbed onto infected skin to } \\
\text { hasten wound and ringworm healing. } \\
\text { Decoctions are orally taken to treat intestinal } \\
\text { worms, including hookworms. } \\
\text { Decoctions are also externally applied to boils } \\
\text { to ensure faster healing. }\end{array}$ & [47] \\
\hline & & & Used as an antiseptic. & [18] \\
\hline & & & $\begin{array}{l}\text { Fresh leaf and stem squeezed together with } \\
\text { water and given orally and also nasally for } \\
\text { livestock to treat leech infection. }\end{array}$ & [48] \\
\hline
\end{tabular}


Table 3. Cont.

\begin{tabular}{|c|c|c|c|c|}
\hline Plant Name & $\begin{array}{c}\text { Ethnic Name } \\
\text { (Z-Zulu; X-Xhosa) }\end{array}$ & Part & Traditional Use & Reference \\
\hline \multirow{9}{*}{ R. tridentata } & \multirow{9}{*}{ Isinwazi $(Z)$} & \multirow{9}{*}{ Roots } & Used as herbal oxytocics. & {$[15]$} \\
\hline & & & $\begin{array}{l}\text { Used with Clivia miniate, Agapanthus africanus, } \\
\text { Pentanisia prunelloides, and Gunnera perpensa to } \\
\text { prepare isihlambezo (that which cleans) } \\
\text { decoctions used by women in the last trimester } \\
\text { of pregnancy. }\end{array}$ & {$[13,15,49-51]$} \\
\hline & & & $\begin{array}{l}\text { Ease of ingestion by use of juice from the roots } \\
\text { extracted through chewing, } \\
\text { care of abdominal pain during menstruation, } \\
\text { treatment of swollen glands through warming } \\
\text { of the roots in fire and pressing them against the } \\
\text { glands, antiemetics in children, broken bones, } \\
\text { cuts, epilepsy, menorrhagia, eye infections, } \\
\text { sexually transmitted infections (STIs), sprained } \\
\text { ankles, stomach ailments, and sores. }\end{array}$ & {$[14,17,19,52]$} \\
\hline & & & $\begin{array}{l}\text { Used in the protection of liver damage, also } \\
\text { known as hepatoprotective effects. }\end{array}$ & {$[53]$} \\
\hline & & & $\begin{array}{l}\text { Its sap is reported to have healing and } \\
\text { anaesthetic properties, and tuberous roots are } \\
\text { boiled and fed to young animals, especially } \\
\text { those that have lost their mothers. }\end{array}$ & {$[19]$} \\
\hline & & & $\begin{array}{l}\text { Used for the treatment of helminth diseases in } \\
\text { cattle and the tick-borne cattle disease, } \\
\text { babesiosis. }\end{array}$ & {$[54,55]$} \\
\hline & & & Used to treat erectile dysfunction. & {$[56]$} \\
\hline & & & $\begin{array}{l}\text { Heartburn, peptic ulcers, diarrhoea, renal } \\
\text { disorders, and infertility in women. }\end{array}$ & {$[57]$} \\
\hline & & & $\begin{array}{l}\text { Heartwater, redwater, internal parasites, } \\
\text { general ailments, and abortion. }\end{array}$ & {$[58]$} \\
\hline
\end{tabular}

\section{Biological Studies of Rhoicissus Species}

\subsection{Anti-Inflammatory Activity}

The research reported on the anti-inflammatory potential of methanolic extracts of $R$. digitata (leaf), $R$. romboidea (root), $R$. tomentosa (leaf/stem), and $R$. tridentata (root) indicated significant inhibition of cyclooxygenase (COX-1) [59,60]. COX-1 is a prostaglandinproducing enzyme that promotes inflammation, pain, and fever, activates platelets, and protects the stomach and intestinal lining. An ethanol indomethacin standard solution $(20 \mu \mathrm{M}$ in the assay) was assayed together with the samples (13.3 $\mathrm{mg}$ for each sample residue) to verify the sensitivity of the assay [59]. The extracts of R. digitata and R. rhomboidea exhibited the highest inhibition of prostaglandin synthesis with $53 \%$ and $56 \%$ inhibition, respectively, compared to $89 \%$ inhibition by the indomethacin standard, suggesting their potential to be used as anti-inflammatory agents $[59,60]$. It was reported that none of the aqueous extracts showed any significant anti-inflammatory activity [59]. Furthermore, $R$. tridentata was investigated with the anti-inflammatory enzyme 15-lipoxygenase (15-LOX). The enzyme (15-LOX) was made up to a final concentration of 200 units/mL in $2 \mathrm{M}$ borate buffer (pH 9), and a volume of $12.5 \mu \mathrm{L}$ of each plant sample and control was added to $487.5 \mu \mathrm{L}$ of 15-LOX [52]. R. tridentata showed a half maximal inhibitory concentration $\left(\mathrm{IC}_{50}\right)$ of $87.39 \mu \mathrm{g} / \mathrm{mL}$ against the 15-LOX enzyme [52]. The results suggested that members of the genus Rhoicissus have the potential to be used as anti-inflammatory agents. 


\subsection{Antimicrobial Activity}

The antimicrobial activities against Gram-positive and Gram-negative microorganisms of the methanolic extracts of $R$. digitata, $R$. rhomboidea, $R$. tomentosa, and $R$. tridentata were investigated [59]. Standard antibiotics, penicillin $\mathrm{G}\left(10 \mathrm{IU} \cdot \mathrm{disc}^{-1}\right)$, tetracycline $\left(30 \mu \mathrm{g} \cdot \mathrm{disc}^{-1}\right)$, and chloramphenicol $\left(30 \mu \mathrm{g} \cdot \mathrm{disc}^{-1}\right)$, were used to eliminate variations between plates [59]. It was found that all extracts showed some degree of antimicrobial activity, with $R$. rhomboidea (root) demonstrating the highest inhibitory activity against different microorganisms. The crude methanolic extracts of $R$. tridentat $a$ and $R$. digitata mainly inhibited Gram-positive and Gram-negative microorganisms. Most of the extracts showed insufficient inhibitory activity towards Salmonella sp. including S. Typhimurium and Shigella sp. (S. boydii and S. flexneri). None of the extracts inhibited Escherichia coli or showed activity against $S$. flexneri. R. digitata (leaf) extract indicated a $>10.00 \mathrm{~mm}$ inhibition zone diameter against $S$. boydii compared to the standard chloramphenicol that showed a $7.00 \mathrm{~mm}$ inhibition zone diameter. Tetracycline showed no activity against $S$. boydii [59] as a standard. $R$. rhomboidei stem extract and the standards chloramphenicol and tetracycline all indicated a $>10.00 \mathrm{~mm}$ inhibition zone diameter against Salmonella sp. [59]. It was also reported that the plant extracts inhibited the Gram-positive microorganisms more than the Gram-negative ones [59].

The antifungal activity of Rhoicissus species was tested using Candida albicans and Saccharomyces cerevisiae [59]. Methanolic extracts of $R$. digitata (leaf) and R. romboidea (root) exhibited the highest antifungal activity against $C$. albicans with an inhibition zone diameter of $>10.00 \mathrm{~mm}$. A methanol extract of $R$. tridentata exhibited antifungal activity against $C$. albicans with an inhibition zone diameter of $7.00 \mathrm{~mm}$ [59].

A study conducted to screen 14 medicinal plants used by the Venda community for infectious diseases supported the antibacterial activities of the methanol extracts of the roots and tubers of $R$. tridentata [61]. Experiments were conducted using $10 \mu \mathrm{L}$ of a $50 \mathrm{mg} / \mathrm{mL}$ gentamycin solution as a positive control and $15 \mu \mathrm{L}(6 \%)$ of dimethyl sulfoxide (DMSO) as a negative control [61]. The extracts of $R$. tridentata showed activities against all the organisms tested with minimum inhibitory concentrations (MICs) varying from $0.75 \mathrm{mg} / \mathrm{mL}$ against Bacillus cereus to $6.00 \mathrm{mg} / \mathrm{mL}$ against Bacillus subtilis, Enterobacter cloacae, and Pseudomonas aeruginosa. The minimum inhibitory concentration of gentamycin was $0.008 \mathrm{mg} / \mathrm{mL}$ against most of the organisms tested and $0.017 \mathrm{mg} / \mathrm{mL}$ for P. aeruginosa and Serratia marcescens [61]. Fruit extracts were not as active as the underground parts and exhibited MICs of more than $12.00 \mathrm{mg} / \mathrm{mL}$ [61].

Antimicrobial properties of the methanol root and leaf extracts of $R$. revoilli were also studied. The extracts were active against three microorganisms: Gram-positive Streptococcus pyogenes, Gram-negative Salmonella typhi, and the fungal pathogen Aspergillus niger [47]. First, $3 \mathrm{~g}$ of the filtered and dried plant extract was constituted with $10 \mathrm{~mL}$ of $100 \%$ cyclohexane to prepare a stock solution. The control had cyclohexane alone without any extract to cancel the effect of the solvent on the test organisms [47]. The growth inhibition diameter was $4.68 \mathrm{~mm}$ for $S$. pyogenes, $5.08 \mathrm{~mm}$ for S. typhi, and $4.27 \mathrm{~mm}$ for A. niger. The root extract showed more significant microbial growth inhibition in comparison to leaf extracts [47]. R. revoilli also displayed inhibitory activity against Staphylococcus aureus at high dilution levels with a $9.00 \mathrm{~mm}$ inhibition zone diameter and showed minimal inhibitory activity against Escherichia coli (8.00 $\mathrm{mm}$ inhibition zone diameter) [62]. The standard, Dettol, showed higher inhibitory activity against $E$. coli $(20.00 \mathrm{~mm}$ inhibition zone diameter) but only at low dilution levels, and inhibitory activity against $S$. aureus was lower than in the case of E. coli with a $12.00 \mathrm{~mm}$ inhibition zone diameter [62]. The ethanol extract of $R$. revoilii rhizomes displayed inhibition zone diameters of $12.82 \mathrm{~mm}$ against $E$. coli and $17.50 \mathrm{~mm}$ against C. albicans [63]. Standard concentrations of $0.12 \mathrm{mg} / \mathrm{mL}$ nystatin and $0.3 \mathrm{mg} / \mathrm{mL}$ chloramphenicol were used as positive controls. About $500 \mathrm{mg}$ of the ethanol extract was triturated with $1 \mathrm{~mL}$ of DMSO and then made up to $5 \mathrm{~mL}$ in distilled water to give a test solution of $100 \mu \mathrm{g} / \mu \mathrm{L}$ concentration for each fraction [63]. These results support the traditional antimicrobial use of $R$. revoilli. 
Different medicinal plants were tested for antifungal activities against five Fusarium species using the whole-plate diffusion method [64]. Sterile dimethyl sulfoxide (DMSO) was used as a negative control, and nystatin was used as a positive control [64]. The methanol extract (roots) of $R$. tridentata was active against Fusarium graminearum with an inhibition zone diameter of $15.00 \mathrm{~mm}$ compared to an inhibition zone diameter of $20.00 \mathrm{~mm}$ for nystatin [64]. The acetone extract (tubers) showed high activities with MIC values ranging between 0.95 and $3.75 \mathrm{mg} / \mathrm{mL}$ against the five Fusarium species tested [64].

Methanol/chloroform $(50 / 50, v / v)$ and ethyl acetate $(100 \%)$ extracts of the rhizomes of $R$. tomentosa were tested against 14 bacterial strains using the disc diffusion and microdilution assay methods [46]. Bacteria most susceptible to rhizome extracts were Staphylococcus aureus (MIC of $0.06 \mathrm{mg} / \mathrm{mL}$ ) and Bacillus subtilis (MIC of $0.13 \mathrm{mg} / \mathrm{mL}$ ) [46]. The results showed that the rhizome extracts of $R$. tomentosa have good antibacterial activity against Gram-positive organisms such as S. aureus, B. subtilis, Enterococcus faecalis $(2.00 \mathrm{mg} / \mathrm{mL})$, Mycobacterium smegmatis $(0.06 \mathrm{mg} / \mathrm{mL})$, Bacillus cereus $(0.50 \mathrm{mg} / \mathrm{mL})$, and Staphylococcus epidermidis $(2.00 \mathrm{mg} / \mathrm{mL})$. In contrast, only the Gram-negative organisms Proteus vulgaris $(8.00 \mathrm{mg} / \mathrm{mL})$ and Proteus mirabilis $(16.00 \mathrm{mg} / \mathrm{mL})$ displayed sensitivity to the extracts [46].

Extracts of selected plant species used to treat sexually transmitted infections (STIs) in southern Africa were investigated for antimicrobial properties and anti-human immunodeficiency virus (HIV) activity against the recombinant HIV-1 enzyme [52]. Doxorubicin at $100 \mu \mathrm{g} / \mathrm{mL}$ was used as the positive control. For the negative control, only the lysis buffer and reaction mixture were added [52]. $R$. tridentata demonstrated the best antimicrobial activity against Neisseria gonorrhoeae with the lowest MIC value of $0.40 \mathrm{mg} / \mathrm{mL}$. C. albicans and Gardnerella vaginalis had MIC values of $0.80 \mathrm{mg} / \mathrm{mL}$ and Oligella ureolytica had an MIC value of $1.60 \mathrm{mg} / \mathrm{mL}$ [52]. R. tridentata also had the best HIV-1 RT inhibition activity of $75.50 \%$ compared to that of the positive control doxorubicin (96.50\%) at $100.00 \mu \mathrm{g} / \mathrm{mL}$ [52]. The observed activities may lead to new multitarget drugs against STIs.

$R$. tridentata (ethanol extract) also displayed activity against C. albicans, E. coli, and S. aureus with an MIC of $0.80 \mathrm{mg} / \mathrm{mL}$ compared to the positive control ciprofloxacin with an MIC of $0.1 \mathrm{mg} / \mathrm{mL}$ [65].

In a related study, traditional medicinal plants used in South Africa to treat urinary tract infections caused by microorganisms were investigated [66]. Ciprofloxacin was used as the positive control at a final concentration of $0.063 \mathrm{mg} / \mathrm{mL}$, while $100 \mu \mathrm{L}$ of $1.0 \%$ DMSO (instead of plant extract) was used as the negative control [66]. The methanol extract of $R$. tridentata displayed the highest activity against Serratia marcescens with an MIC of $0.13 \mathrm{mg} / \mathrm{mL}$ [66]. The positive control ciprofloxacin presented an MIC of $<0.063 \mathrm{mg} / \mathrm{mL}$. The polar extracts of $R$. tridentata were able to reduce the initial cell attachment of $S$. aureus, P. mirabilis, and Serratia marcescens by approximately 50\% [66]. The quantitative antiquorum sensing assay indicated that the methanol extract of $R$. tridentata inhibited violacein production by C. violaceum by more than $50 \%$, with an $\mathrm{IC}_{50}$ of $2.58 \mathrm{mg} / \mathrm{mL}$ [66]. The positive control eugenol was $1.73 \mathrm{mg} / \mathrm{mL}$ [66]. The results validate the use of $R$. tridentata to treat urinary tract infections (UTIs) and indicate that this plant may be a suitable source of antipathogenic drugs to treat UTIs [66].

\subsection{Antiproliferative Activity}

Aqueous and methanol extracts of $R$. digitata, R. rhomboidea, R. tomentosa, and $R$. tridentata were screened to determine their therapeutic potentials as anticancer agents [14]. The antiproliferative activity in vitro against HepG2 cells, a human liver cancer cell line, was determined. The aqueous root extract of $R$. tridentata subsp. cuneifolia displayed the highest antiproliferative activity, with a $96.27 \%$ inhibition of proliferation compared with the other crude plant extracts [14]. The methanol extract of $R$. tridentata also presented a more potent inhibition of $87.01 \%$. The crude root extract of $R$. tomentosa exhibited $70.40 \%$ inhibition of proliferation [14]. The results from this study demonstrated that all the Rhoicissus species screened have potential antineoplastic activity against the HepG2 cell 
line, and the root extracts demonstrated stronger inhibitory activities compared with the leaf and stem extracts [14].

\subsection{Antioxidant Activity}

The antioxidant activity of $R$. tridentata was $0.06 \mu \mathrm{g} / \mathrm{mL}$, lower than that of vitamin $\mathrm{C}$ $\left(\mathrm{IC}_{50}\right.$ of $\left.1.44 \mu \mathrm{g} / \mathrm{mL}\right)$ [65]. In this study, $2 \mathrm{mg}$ plant samples were tested at concentrations ranging from 500-3.91 $\mu \mathrm{g} / \mathrm{mL}$. Ascorbic acid (vitamin C) was used as a positive control, and ethanol was used as a solvent control (blank) [65].

Methanol extracts of the roots, stems, and leaves of four Rhoicissus species (R. digitate, $R$. rhomboidea, $R$. tomentosa, and $R$. tridentata) were tested for antioxidant activity [67]. Commercial antioxidants vitamin E, butylated hydroxytoluene (BHT), and hydroxyanisole (BHA) were used as standards [67]. The extracts of $R$. rhomboidea and $R$. tridentata revealed more than $50 \%$ antioxidant activity compared with values obtained for the commercial antioxidants. The commercial antioxidants gave the following results vitamin E, 63\%; butylated hydroxytoluene (BHT), 50.10\%; butylated hydroxyanisole (BHA), 42.50\% [67]. $R$. rhomboidea and $R$. tridentata inhibited the 1, $1^{\prime}$-diphenyl-2-picrylhydrazyl free radical with approximately $98 \%$ radical scavenging activity. Xanthine oxidase was inhibited by $88.20 \%$ by the root extract of $R$. rhomboidei. The stem of $R$. tridentata exhibited an inhibitory effect above $70 \%$ against xanthine oxidase. It also prevented the production of thiobarbituric acid-reactive substances and free radical-mediated DNA sugar damage (catechin showed an $85.40 \%$ inhibitory effect) [67].

The four Rhoicissus extracts had a strong chelating effect on $\mathrm{Fe}^{2+}$ ions, especially the leaves of $R$. tridentata [67]. R. digitata and $R$. tomentosa extracts possessed pro-oxidative properties at high concentrations $(2.50 \mathrm{mg} / 100 \mathrm{~mL})$ due to the presence of the plant phenolics [67]. The results indicate that the four Rhoicissus species have a protective action against the overproduction of free radicals. One of the mechanisms of action suggests that $R$. rhomboidea and $R$. tridentata contain compounds (polyphenols) with strong radicalscavenging and antiradical-generating effects.

\subsection{Uterotonic Activity}

Pharmacological investigation of crude aqueous extracts of $R$. tridentata roots displayed direct contractile responses in isolated rat uterus and ileum [68]. The muscarinic receptor system and the produced cyclooxygenase metabolites facilitated the contractile response to the extract [68]. The results provide evidence justifying the ethnomedical use of this plant to promote quick and uncomplicated labour. The potential exists for the plant decoctions to cause birth complications caused by increased uterine contractility [68]. It was also confirmed that the contractile activity of $R$. tridentata extracts varies seasonally to different plant parts [51]. The activity of the plant extracts from plants harvested in summer and autumn were 4-5-fold higher than extracts from plants harvested in winter or spring. The lignotubers stimulated the most significant number of contractions, followed by the stems, roots, and leaves [51].

Aqueous extracts of the roots of $R$. tridentata revealed notable in vitro activity on isolated rat uterine smooth muscle tissue [15]. Extracts with the highest activity also contained proanthocyanidin monomers, dimers, gallic acid, and 74\% polymeric proanthocyanidins [15]. Glucose and a hydrogel of glucose extracted from the methanol root extract also greatly stimulated uterine muscle contraction [15]. $\beta$-Sitosterol and its glucoside, sitosterolin, exhibited only slight oestrogenic activity, increasing the response of the uterus by about $2 \%$ at concentrations of acetylcholine below $10^{-7} \mathrm{M}$ and $10^{-5} \mathrm{M}$, respectively, and inhibiting this response at higher acetylcholine concentrations [15].

Furthermore, the chloroform and ethanol extracts of the root bark of $R$. tridentata were investigated for their in vitro activity on the contraction of corpus cavernosum smooth muscle of white New Zealand rabbits [56]. The extracts stimulated dose-dependent relaxation in the muscle at concentrations of 13.00 and $6.50 \mathrm{mg} / \mathrm{mL}$ [56]. At an extract concentration of $13.00 \mathrm{mg} / \mathrm{mL}$, the relaxation induced was significantly higher 
$(p<0.01,30.70 \pm 3.3$ chloroform extract and $43.00 \pm 9.4$ ethanol extract) than that seen with $3.2 \times 10^{-5} \mathrm{mg} / \mathrm{mL}$ of the positive control Viagra [56]. This study indicated that $R$. tridentata is a promising candidate for the treatment of erectile dysfunction.

\subsection{Cytotoxicity}

The ethanol extract of $R$. tridentata showed moderate toxicity with a half maximal effective concentration $\left(\mathrm{EC}_{50}\right)$ of $88.50 \pm 0.09 \mu \mathrm{g} / \mathrm{mL}$, whereas actinomycin D exhibited an $\mathrm{IC}_{50}$ value of $0.00932 \mu \mathrm{g} / \mathrm{mL}$ [65]. Actinomycin D ranging from 400-3.13 and 0.013 to $0.0001 \mu \mathrm{g} / \mathrm{mL}$ was used as a positive control for the cytotoxicity assay. The toxicity effects of the samples were determined using $50 \mu \mathrm{L}$ of XTT reagent $(1 \mathrm{mg} / \mathrm{mL}$ 2,3-bis-(2-methoxy4-nitro-5-sulfophenyl)-2H-tetrazolium-5-carboxanilide (XTT) with $0.383 \mathrm{mg} / \mathrm{mL} \mathrm{N}$-methyl dibenzopyrazine methyl sulphate (PMS)) [65].

The cytotoxicity of the aqueous extracts from $R$. tridentata was studied using monkey Vero cells and human fibroblasts [50]. The threshold for zero cell deaths was $8.00 \mu \mathrm{g} / \mathrm{mL}$ for monkey Vero cells. At this concentration, 100\% of human fibroblast cells also survived [50]. The estimated concentration in the bloodstream was $6.10 \mu \mathrm{g} / \mathrm{mL}$, taking dilutions into account. It was then concluded that $R$. tridentata is not toxic at a cellular level since the estimated cell concentrations were below the thresholds for zero cell death for monkey Vero cells, which is $8.00 \mu \mathrm{g} / \mathrm{mL}$ [50]. The nontoxic nature of this species was also demonstrated using human hepatoma, kidney epithelial, histiocytoma, and mouse Leydig cells [15].

\subsection{Hepatoprotective Activity}

The identity of catechins and the in vitro antioxidative properties of $R$. tridentata motivated a study to investigate the in vivo hepatoprotective effects of $R$. tridentata against $\mathrm{CCl}_{4}$-induced acute liver injury in rats $[53,55,67]$. The variables investigated were the alanine aminotransferase (ALT), aspartate aminotransferase (ASP), glucose-6-phosphatase (G-6-Pase), and lipid peroxide (LPO) levels of liver homogenates. Liver microsomal fractions were investigated as malondialdehyde (MDA) levels [53]. The results displayed a decrease in the concentration of ALT, ASP, and LPO $(p<0.05)$ after the administration of the plant extract to the $\mathrm{CCl}_{4}$-intoxicated rats. In contrast, the G-6-Pase concentration was elevated $(p<0.05)$ in the plant extract-treated rats, and this shows that $R$. tridentata has components with hepatoprotective properties [53].

\subsection{Ascaricidal Activity}

The in vitro anthelmintic activity of the extracts of $R$. tridentata was tested, and the median effective dose $\left(\mathrm{ED}_{50}\right)$ values of the extracts were determined using the Ascaris model [54]. The $\mathrm{ED}_{50}$ of $R$. tridentata was found to be $4.36 \mathrm{mg} / \mathrm{mL}$ [54]. The highest dose of $10.00 \mathrm{mg} / \mathrm{mL}$ first showed activity at $12 \mathrm{~h}$, achieving a maximum response of $100 \%$ at $24 \mathrm{~h}$. Doses of 4.00, 6.00, and $8.00 \mathrm{mg} / \mathrm{mL}$ first showed activity at $12 \mathrm{~h}$. The maximum response was achieved at $48 \mathrm{~h}$ for doses of 4.00 and $6.00 \mathrm{mg} / \mathrm{mL}$. After $36 \mathrm{~h}$, the maximum response was achieved for $8.00 \mathrm{mg} / \mathrm{mL}$. The lowest dose of $2.00 \mathrm{mg} / \mathrm{mL}$ started a response at $24 \mathrm{~h}$ and only achieved a $90 \%$ response at $48 \mathrm{~h}$ [54]. These results show that $R$. tridentata can be used for the treatment of helminth diseases in cattle.

A study to determine in vitro ascaricidal activity of ethanolic and water extract of roottuber $R$. tridentata against adult nematodes was conducted [69]. The in vitro adult motility inhibition assay revealed that the two extracts exhibited motility inhibition, and the ethanolic extract was more potent [69]. The ascaricidal single-dose effect increased with increasing concentration of the extract. The highest concentrations of 64.00 and $128.00 \mathrm{mg} / \mathrm{mL}$ for ethanol and water extracts gave a maximum mean percentage ascaricidal activity by $48 \mathrm{~h}$ as $80.00 \pm 10.0 \%$ and $90.00 \pm 0.6 \%$, respectively [69]. The crude extract's potential to control gastrointestinal nematodes was indicated by the low $\mathrm{ED}_{50}$ of $25.00 \mathrm{mg} / \mathrm{mL}$ [69]. 


\subsection{Antidiabetic Activity}

A study was designed to evaluate the antidiabetic potential of aqueous leaf extracts of $R$. tridentata in alloxan-induced diabetic mice [19]. The aqueous leaf extracts showed antidiabetic activity. Intraperitoneally and orally administered aqueous whole-stem extracts of $R$. tridentata decreased the blood glucose levels at all four doses of 50.00, 100.00, 200.00, and $300.00 \mathrm{mg} / \mathrm{kg}$ body weight, from the first hour to the sixth hour in a dose-independent manner [19]. The intraperitoneal route of herbal extract administration was more effective than the oral route [19].

\section{Phytochemistry of Some Species of the Rhoicissus Genus}

The study of chemical compounds found in plants is essential for drug discovery and for developing novel therapeutic agents against significant diseases as they are biologically active. Different species of the Rhoicissus genus have been shown to possess bioactive compounds such as coumarins, flavonoids, phytosterols, essential oils, saponins, terpenoids, alkaloids, reducing sugars, and tannins, which are the reason for their use in traditional medicine. The phytochemical screening carried out on the rhizomes of $R$. tomentosa revealed the presence of many known groups of bioactive compounds: alkaloids, flavonoids, saponins, steroids, reducing sugars, and tannins [46].

While there have been many investigations on the pharmacological activities of this genus, little has been achieved concerning the isolation and identification of bioactive compounds. It is established that few chemical constituents have been isolated from these species within the review period, as most of the chemical constituents have been profiled from the crude extracts. This limits further studies aimed at advancing the bioactive constituents to clinical trials.

Among the identified compounds, essential oils and other phenolic acids (1-14) were predominant. Other compounds included triterpenoids such as 12,13-dehydrolupeol (21), 3 $\beta$-taraxerol (23), and stigmasterol (24), as well as flavonoids such as quercetin (22), quercetrin (25), and aromadendrin-7-O- $\beta$-glucopyranoside (26), among others, as illustrated in Tables 4 and 5 and Figures $2-4$.

Table 4. Compounds identified in $R$. tomentosa rhizomes and their biological activities.

\begin{tabular}{|c|c|c|c|}
\hline $\begin{array}{l}\text { Compound } \\
\text { Number }\end{array}$ & Name of Compound & Biological Activity & Reference \\
\hline 1 & D-Asparagine & Immuno-stimulant, antibacterial, anti-infective, and analgestic activities. & [70] \\
\hline 2 & L-Arginine & Anti-inflammatory, immunostimulant, and antihypertensive activities. & [71] \\
\hline 3 & Glycyl-L-valine & Analgesic, antipyretic, antioxidant, and anti-inflammatory activities. & [72] \\
\hline 4 & Uridine & $\begin{array}{l}\text { Neuroprotective activity, pyrimidine metabolism, antidepressant, and } \\
\text { antiepileptic actions. }\end{array}$ & [73] \\
\hline 5 & Tetradecanoic acid & Antipruritic, antifungal, anti-infective, and antioxidant activities. & [74] \\
\hline 6 & Hexadecanoic acid & Antioxidant, antibacterial, anthelmintic, and antifungal activities. & [75] \\
\hline 7 & Octadecanoic acid & Antifungal, antitumor, antibacterial, and antioxidant activities & [76] \\
\hline 8 & Eicosanoic acid & $\begin{array}{l}\text { Anti-abortifacient, antioxidant, antibacterial, analgesic, and antipyretic } \\
\text { activities. }\end{array}$ & [77] \\
\hline 9 & Docosanoic acid & Antipruritic, antioxidant, and anaesthetic activities & \\
\hline 10 & Tetracosanoic acid & Antibacterial activity. & [78] \\
\hline 11 & Hexadecanoic acid, methyl ester & Antispasmodial, antioxidant, and antiabortifacient activities. & [79] \\
\hline 12 & Decanoic acid, 2-propenyl ester & $\begin{array}{c}\text { Analgesic, antipyretic, antibacterial, antifungal, and anti-inflammatory } \\
\text { activities. }\end{array}$ & [80] \\
\hline 13 & cis-9-Octadecenoic acid & $\begin{array}{c}\text { Antioxidant, anti-inflammatory, antitumor, antispasmodial, and } \\
\text { antimicrobial activities. }\end{array}$ & [81] \\
\hline 14 & 9-Octadecynoic acid & Antifungal, cytotoxicity, antiasthmatic, and antidepressant activities. & [82] \\
\hline
\end{tabular}


<smiles>NC(=O)CC(N)C(=O)O</smiles>

1<smiles>O=C1CCN([C@@H]2O[C@H](CO)[C@@H](O)[C@H]2O)C(=O)N1</smiles>

4<smiles>CCCCCCCCCCCCCCCC(=O)OC</smiles>

11<smiles>C=CCOC(=O)CCCCCCCCC</smiles>

12<smiles>CCCCCCCC/C=C\CCCCCCCC(=O)O</smiles>

13<smiles>[R]C(CC(=O)O)C(=O)O</smiles>

$15 \mathrm{R}=\mathrm{OH}$<smiles>O=C(O)C=CC(=O)O</smiles>

17<smiles>CC(C)C(NC(=O)CN)C(=O)O</smiles><smiles>[R]CCCCCCCCCC(=O)O</smiles>

$7 \mathrm{R}=\mathrm{C}_{5} \mathrm{H}_{11}$

$8 \mathrm{R}=\mathrm{C}_{7} \mathrm{H}_{15}$

$9 \mathrm{R}=\mathrm{C}_{9} \mathrm{H}_{19}$

$10 \mathrm{R}=\mathrm{C}_{11} \mathrm{H}_{23}$<smiles>CCCCCCCCC#CCCCCCCCC(=O)O</smiles>

14<smiles>[R]c1cc(C(=O)O)cc([R])c1O</smiles>

$18 \mathrm{R}=\mathrm{OH} ; \mathrm{R}^{\prime}=\mathrm{OH}$

$19 \mathrm{R}=\mathrm{H} \quad \mathrm{R}^{\prime}=\mathrm{OCH}_{3}$<smiles>COc1cc(/C=C/C(=O)O)ccc1O</smiles>

20

Figure 2. Chemical structures of acids isolated from the genus Rhoicissus.

Organic acids (malic (15), succinic (16), and fumaric acids (17)) (Figure 2) were also detected in the free phenolic fraction and malonoic and propanoic acids were detected in the hydrolysable fraction of $R$. tridentata [17]. Homovanillyl alcohol was found in the free phenolic fraction, and gallic (18), vanillic (19), and ferulic acids (20) (Figure 2) were confirmed in the bound phenolic fraction [17]. Qualitative and quantitative phytochemical screening of the aqueous leaf extracts of $R$. tridentata also indicated the presence of phenols, alkaloids, flavonoids, tannins, and saponins [19]. R. tridentata is known to contain a high concentration of polyphenolic compounds $[55,67]$. The phytochemical screening of $R$. revoilli revealed active compounds such as flavonoids, alkaloids, saponins, steroids, and anthraquinones. Aldehydes were detected in the leaf extract [47]. However, these compounds were not structurally elucidated. 
<smiles>C=C(C)[C@@H]1CCC2(C)CC[C@]3(C)C(=CCC4[C@@]5(C)CC[C@@H](O)C(C)(C)C5CC[C@]43C)C12</smiles>

21<smiles>CCC(/C=C/[C@H](C)[C@H]1CCC2C3CC=C4CC(O)CCC4(C)C3CCC2(C)[C@H]1C)C(C)C</smiles>

24<smiles>O=C1c2c(O)cc(OC3OC(CO)C(O)C(O)C3O)cc2O[C@H](c2ccc(O)cc2)C1O</smiles>

26

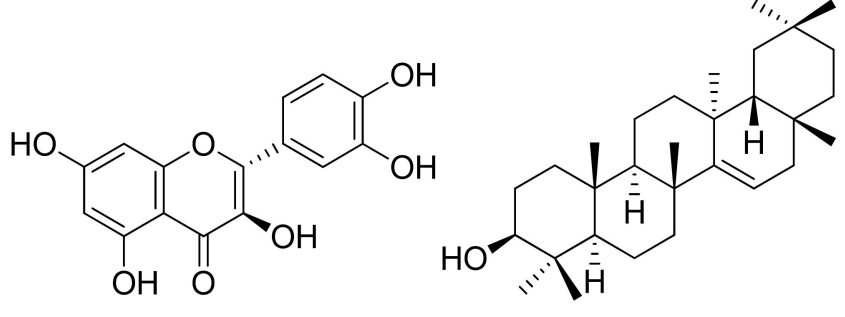

22<smiles></smiles>

25 
<smiles>[R3]c1cc([C@@H]2Oc3cc(O)cc([R])c3C([R2])[C@H]2O)cc(O)c1O</smiles>

$$
\begin{array}{lll}
\mathrm{R}_{1} & \mathrm{R}_{2} & \mathrm{R}_{3}
\end{array}
$$

$\begin{array}{llll}34 & \mathrm{OH} & \mathrm{H} & \mathrm{H}\end{array}$

$\begin{array}{llllllllll}35 & \mathrm{OH} & \mathrm{H} & \mathrm{OH}\end{array}$

$\begin{array}{lllll}36 & \mathrm{H} & \mathrm{H} & \mathrm{H}\end{array}$

$\begin{array}{lllll}37 & \mathrm{H} & \mathrm{OH} & \mathrm{H}\end{array}$<smiles>[R6]C1Cc2c(O)ccc([C@@H]3c4ccc(O)cc4O[C@H](c4ccc(O)c(O)c4)[C@H]3O)c2O[C@H]1c1ccc(O)c(O)c1</smiles>

$\begin{array}{ll}R_{6} & R_{7}\end{array}$

$41 \quad \mathrm{OH} \quad \beta-\mathrm{OH}$

$42 \quad \mathrm{OH} \quad \alpha-\mathrm{OH}$

$43 \quad \mathrm{H} \quad \beta-\mathrm{OH}$<smiles>[R]c1cc([C@H]2Oc3cc(O)cc(O)c3CC2[R5])cc(O)c1O</smiles>

$\begin{array}{ll}\mathrm{R}_{4} & \mathrm{R}_{5}\end{array}$

$\begin{array}{lll}38 & \mathrm{H} & \mathrm{OH}\end{array}$

$39 \mathrm{OH} \quad \mathrm{OH}$

40<smiles>[14CH3]OC(=O)c1cc(O)c(O)c(O)c1</smiles>

44

Figure 4. Structures of proanthocyanidin monomers and dimers from genus Rhoicissus.

A phytochemical investigation of the roots and fruits of $R$. digitata led to the isolation of triterpenes and flavonoids [44]. From the roots, leaves, and fruits of $R$. tomentosa, terpenoids, flavonoids, an alkaloid, and a carotenoid were isolated, as illustrated in Table 5 and Figure 3 [44]. Moreover, the leaf extracts of $R$. tomentosa tested positive for coumarins, flavonoids, phytosterols, essential oils, saponins, terpenoids, and resveratrol, and the hexane and ethyl acetate/hexane (1:4) extracts of $R$. tomentosa were submitted for GC-MS analysis [83]. 
Table 5. Compounds isolated from Rhoicissus species.

\begin{tabular}{|c|c|c|c|c|c|}
\hline Plant Name & Class & Number & Name & Biological Activity & Reference \\
\hline \multirow{5}{*}{ R. digitata } & \multirow{3}{*}{ Triterpenoids } & 21 & $\begin{array}{c}12,13- \\
\text { Dehydrolupeol }\end{array}$ & $\begin{array}{l}\text { Anti-inflammatory, antitumor, } \\
\text { chemopreventive, hepatoprotective, } \\
\text { cardioprotective, and antiarthritic }\end{array}$ & {$[44,84]$} \\
\hline & & 32 & $\beta$-Sitosterol & $\begin{array}{c}\text { Antidiabetic, neuroprotective, } \\
\text { chemoprotective agent, antioxidant, } \\
\text { anti-inflammatory, } \\
\text { hypocholesterolemic, inducing } \\
\text { apoptosis, angiogenic, anthelminthic, } \\
\text { and immunomodulatory }\end{array}$ & {$[44,85]$} \\
\hline & & 31 & Oleanolic acid & $\begin{array}{l}\text { Anticancer, antiosteoporosis, } \\
\text { antiobesity, antidiabetic, lipid-lowering, } \\
\text { anti-inflammatory, antioxidant, } \\
\text { immune-regulatory, and } \\
\text { hepatoprotective effects }\end{array}$ & {$[44,86]$} \\
\hline & \multirow[b]{2}{*}{ Flavonoids } & 34 & $(+)$-Catechin & $\begin{array}{l}\text { Antioxidant, antimicrobial, } \\
\text { antimutagenic, anticarcinogenic, and } \\
\text { cardioprotective }\end{array}$ & {$[44,87]$} \\
\hline & & 22 & Quercetin & $\begin{array}{l}\text { Antioxidant (peroxonitrite }\left(\mathrm{ONOO}^{-}\right) \\
\text {half maximal inhibitory concentration } \\
\qquad\left(\mathrm{IC}_{50}\right)=8.6 \mu \mathrm{M} \text {; } \\
\text { 2,2-diphenyl-1-picrylhydrazyl }(\mathrm{DPPH}) \\
\left.\mathrm{IC}_{50}=27.6 \mu \mathrm{M}\right) \text {, anti-inflammation, } \\
\text { antiviral, antiobesity, and } \\
\text { antidepressant, as well as preventing } \\
\text { cancer, diabetes, asthma, hypertension, } \\
\text { and cardiovascular diseases }\end{array}$ & {$[44,88]$} \\
\hline \multirow{9}{*}{ R. tomentosa } & \multirow{4}{*}{ Terpenoids } & 23 & $3 \beta$-Taraxerol & Antidiabetic, anti-inflammatory & {$[44,89]$} \\
\hline & & 24 & Stigmasterol & $\begin{array}{l}\text { Antiosteoarthritic, } \\
\text { antihypercholestrolemic, cytotoxicity, } \\
\text { antitumor, hypoglycaemic, } \\
\text { antimutagenic, antioxidant, } \\
\text { anti-inflammatory, and central nervous } \\
\text { system (CNS) effects }\end{array}$ & {$[44,90]$} \\
\hline & & 25 & Oleanolic acid & & [44] \\
\hline & & 32 & $\beta$-Sistosterol & & [44] \\
\hline & \multirow{3}{*}{ Flavonoids } & 25 & Quercetrin & & {$[44]$} \\
\hline & & 34 & (+)-Catechin & & {$[44]$} \\
\hline & & 26 & $\begin{array}{l}\text { Aromadendrin-7- } \\
\text { O- } \beta \text { - } \\
\text { glucopyranoside }\end{array}$ & & [44] \\
\hline & Alkaloid & 27 & Pheophytin & $\begin{array}{c}\text { Neuroprotective, } \\
\text { antimutagenic, anti-inflammatory }\end{array}$ & {$[44,91]$} \\
\hline & Carotenoid & 28 & Lutein & $\begin{array}{l}\text { Antioxidant, antiarthritis, } \\
\text { anti-inflammatory, hepatoprotective, } \\
\text { cardioprotective, anticataract, } \\
\text { antidiabetic, anticancer, and bone } \\
\text { remodelling activities }\end{array}$ & {$[44,92]$} \\
\hline
\end{tabular}

Previously undescribed compounds from the species were isolated from the extracts of $R$. tridentata [15]. The proanthocyanidin monomers and dimers from the methanol root extract were identified as follows using HPLC: catechin (34), gallocatechin (35), fisetinidol (36) mollisacacidin (37), epicatechin (38), epigallocatechin (39), epicatechin-3-O-gallate (40), 
procyanidin B3 (41), procyanidin B4 (42), fisetinidol (4 $\alpha-8)(43)$, fisetinidol $(4 \beta-8)$, catechin (44) (Figure 4), andgallic acid (18) (Figure 2).

Glucose and a partially identified hydrogel of glucose were also isolated from the methanol root extract. Oleanolic acid (31) was isolated from a chloroform extract. The nonpolar fraction yielded two further triterpenoids, 20(29)-lupen-3-one (29) and 20-epi- $\psi$ taraxastananol (30), as well as $\gamma$-sitosterol (33), which were identified by gas chromatographymass spectrometry (Figure 3). From the extract of branches, the plant growth hormone triacontanol was purified [15].

Most of the isolated compounds have documented health-promoting properties. It supports their use by traditional healers to promote good health during pregnancy. Proanthocyanidins are potent antioxidants beneficial for the heart, cardiovascular, and immune systems (Figure 4). Lupenone (29) has antibiotic and antioxidant activity [93]. Triacontanol has cholesterol-lowering properties, and the triterpenoids such as oleanolic acid (31), lupenone (29), and taraxastananol (30) are well known for their anti-inflammatory properties $[15,94]$.

\section{Conclusions}

$R$. tridentata is used to treat various ailments including erectile dysfunction, pains, swelling, cuts, wounds, kidney and bladder complications, stomach ailments, and livestock diseases, as well as for gynaecological purposes. Compounds isolated from $R$. tridentata include proanthocyanidin monomers and dimers, phenols, alkaloids, flavonoids, tannins, saponins, organic acids, and triterpenoids. Pharmacological studies indicated that Rhoicissus species exhibited antitumor, antispasmodic, antipruritic, anaesthetic, neuroprotective, analgesic, antipyretic, antidepressant, antiepileptic, anthelmintic, antiasthmatic, antidiabetic, uterotonic, ascaricidal, hepatoprotective, antibacterial, antidiabetic, antioxidant, antimicrobial, antifungal, anticancer, and anti-inflammatory properties. These results are encouraging and indicate that Rhoicissus is an essential source of many pharmacologically and medicinally important compounds. Hence, this plant has the potential as an alternative therapeutic strategy to treat diseases and can be used as part of a template for developing safer and powerful drugs to combat diseases. The observed biological activities of the members of Rhoicissus support the medicinal use of these plants by traditional healers. However, no specific compound class has been identified or linked to a particular ethnomedicinal application of these species. Their prescription, mechanisms, associated side-effects, and/or proven efficacy are also not clear. Thus, there is a need for more detailed studies to establish the missing information.

While many investigations into the pharmacological activities of the genus Rhoicissus have been done, little has been achieved concerning the isolation and identification of bioactive compounds. Only a few chemical constituents have been isolated from these species within the review period. This limits further studies aimed at advancing the bioactive constituents to clinical trials. Studies focusing on the biological activities of Rhoicissus have been conducted in vitro, and little data are available on the biological activities of compounds isolated from the species. There is a need for further studies focusing on the phytochemistry, pharmacological, and toxicological properties, as well as in vivo studies involving the crude extracts and chemical compounds isolated from the species. New techniques such as high-throughput screening, molecular docking studies, and metabolomics should be advanced, especially for complex plant matrices.

Author Contributions: N.P.D. conceptualised, read, reviewed, and wrote the original draft of the manuscript; X.S.-N., R.W.M.K., D.K., V.J.T. and A.-L.M. read, reviewed, corrected, and provided insights into the occurrence, distribution, traditional uses, phytochemistry, and pharmacological properties of Rhoicissus species. All authors have read and agreed to the published version of the manuscript.

Funding: This research was funded by the National Research Foundation, grant number 121119, and Tshwane University of Technology, Pretoria, South Africa. 
Institutional Review Board Statement: Not applicable.

Informed Consent Statement: Not applicable.

Data Availability Statement: Not applicable.

Acknowledgments: The authors are grateful to Leonie Goosen for proofreading the manuscript.

Conflicts of Interest: The authors declare no conflict of interest. Funders had no role in the design of the study, in the collection, analyses, or interpretation of data, in the writing of the manuscript, or in the decision to publish the results.

$\begin{array}{ll}\text { Abbreviations } \\ \text { ANOVA } & \text { one-way analysis of variance } \\ \text { ALT } & \text { alanine amino transferase } \\ \text { ASP } & \text { aspartate amino transferase } \\ \text { ATP } & \text { adenoside triphosphate } \\ \text { BHA } & \text { butylated hydroxyanisole } \\ \text { BHT } & \text { butylated hydroxy toluene } \\ \text { CCl } & \text { carbon tetrachloride } \\ \text { COX } & \text { cyclooxygenase } \\ \text { DMSO } & \text { dimethyl sulfoxide } \\ \text { DNA } & \text { deoxyribonucleic acid } \\ \text { G-6-Pase } & \text { glucose-6-phosphate } \\ \text { LOX } & \text { lipo-oxygenase } \\ \text { LPO } & \text { lipid peroxide } \\ \text { MIC } & \text { minimum inhibitory concentration } \\ \text { STI } & \text { sexually transmitted infection } \\ \text { TGF- } \beta 1 & \text { transforming growth factor- } \beta 1 \\ \text { UTI } & \text { urinary tract infection }\end{array}$

\section{References}

1. Rahmatullah, M.; Ferdausi, D.; Mollik, A.H.; Jahan, R.; Chowdhury, M.H.; Haque, W.M. A Survey of Medicinal Plants Used by Kavirajes of Chalna Area, Khulna District, Bangladesh. Afr. J. Tradit. Complement. Altern. Med. 2010, 7, 91-97. [CrossRef]

2. Greenwell, M.; Rahman, P. Medicinal Plants: Their Use in Anticancer Treatment. Int. J. Pharm. Sci. Res. 2015, 6, 4103-4112. [CrossRef] [PubMed]

3. Rahman, A.M. A Review on Medicinal Plants with Anticancer Activity Available In Bangladesh. Mod. Appl. Pharm. Pharmacol. 2018, 1, 4. [CrossRef]

4. Shabani, A. A review of Anticancer Properties of Herbal Medicines. J. Pharm. Care Health Syst. 2016, 3, 160. [CrossRef]

5. Jain, S.; Dwivedi, J.; Jain, P.K.; Satpathy, S.; Patra, A. Medicinal Plants for Treatment of Cancer: A Brief Review. Pharmacogn. J. 2016, 8, 87-102. [CrossRef]

6. Ayele, T.T. A Review on Traditionally Used Medicinal Plants/Herbs for Cancer Therapy in Ethiopia: Current Status, Challenge and Future Perspectives. Org. Chem. Curr. Res. 2018, 7, 1-8. [CrossRef]

7. Farnsworth, N.R.; Akerele, O.; Bingel, A.S. Medicinal plants in therapy. J. Ethnopharmacol. 1987, 19, 336. [CrossRef]

8. Koduru, S.D.S.; Grierson, D.S.; Afolayan, A.J. Ethnobotanical information of medicinal plants used for treatment of cancer in the Eastern Cape Province. S. Afr. Curr. Sci. 2007, 92, 906-908.

9. Pandey, M.; Debnath, M.; Gupta, S.; Chikara, S.K. Phytomedicine: An ancient approach turning into future potential source of therapeutics. J. Pharmacogn. Phytother. 2011, 3, 27-37. [CrossRef]

10. Iqbal, J.; Abbasi, B.A.; Mahmood, T.; Kanwal, S.; Ali, B.; Shah, S.A.; Khalil, A.T. Plant-derived anticancer agents: A green anticancer approach. Asian Pac. J. Trop. Biomed. 2017, 7, 1129-1150. [CrossRef]

11. Khan, R.A. Natural products chemistry: The emerging trends and prospective goals. Saudi Pharm. J. 2018, 26, 739-753. [CrossRef]

12. Balunas, M.J.; Kinghorn, A.D. Drug discovery from medicinal plants. Life Sci. 2005, 78, 431-441. [CrossRef]

13. Veale, D.; Furman, K.; Oliver, D. South African traditional herbal medicines used during pregnancy and childbirth. J. Ethnopharmacol. 1992, 36, 185-191. [CrossRef]

14. Opoku, A.R.; Geheeb-Keller, M.; Lin, J.; Terblanche, S.E.; Hutchings, A.; Chuturgoon, A.; Pillay, D. Preliminary screening of some traditional Zulu medicinal plants for antineoplastic activities versus the HepG2 cell line. Phytother. Res. 2000, 14, 534-537. [CrossRef]

15. Brookes, K.B.; Katsoulis, L.C. Bioactive components of Rhoicissus tridentata: A pregnancy-related traditional medicine. S. Afr. J. Sci. 2006, 103, 187-189. [CrossRef] 
16. Liengme, C.A. Plants used by the Tsonga people of Gazankulu. Bothalia 1981, 13, 501-518. [CrossRef]

17. Steenkamp, V.; Nkwane, O.; van Tonder, J.; Dinsmore, A.; Gulumian, M. Evaluation of the phenolic and flavonoid contents and radical scavenging activity of three southern African medicinal plants. Afr. J. Pharm. Pharmacol. 2013, 7, 703-709. [CrossRef]

18. Kamita, M.K.; Matu, E.N.; Njenga, E.W.; Wanga, J.; Amalemba, G.; Kigondo, E.V.M. In vivo antifertility activity and phytochemical screening of selected Kenyan medicinal plants. Afr. J. Pharmacol. Ther. 2014, 3, 85-94.

19. Mukundi, M.J.; Mwaniki, N.E.; Ngugi, M.P.; Njagi, J.M.; Agyirifo, S.D.; Gathumbi, K.P.; Muchugi, N.A. In Vivo Anti-diabetic Effects of Aqueous Leaf Extracts of Rhoicissus tridentata in Alloxan Induced Diabetic Mice. J. Dev. Drugs 2015, 4, 1-5. [CrossRef]

20. Urton, N.R.; Olivier, M.C.; Robertson, B. The taxonomy of the Rhoicissus tridentata (Vitaceae) complex in southern Africa. S. Afr. J. Bot. 1986, 52, 389-396. [CrossRef]

21. Germishuizen, G.; Meyer, N.L. Plants of Southern Africa: An Annotated Checklist; Strelitzia 14; National Botanical Institute: Pretoria, South Africa, 2003; Volume 14, pp. 192-196.

22. Punt, W.; Marks, A.; Hoen, P. The Northwest European pollen flora, 64: Vitaceae. Rev. Palaeobot. Palynol. 2003, 123, 67-70. [CrossRef]

23. Wen, J.; Nie, Z.-L.; Soejima, A.; Meng, Y. Phylogeny of Vitaceae based on the nuclear GAI1 gene sequencesThis article is one of a selection of papers presented at the symposium on Vitis at the XVII International Botanical Congress held in Vienna, Austria, in 2005. Can. J. Bot. 2007, 85, 731-745. [CrossRef]

24. Manchester, S.R.; Kapgate, D.K.; Wen, J. Oldest fruits of the grape family (Vitaceae) from the Late Cretaceous Deccan Cherts of India. Am. J. Bot. 2013, 100, 1849-1859. [CrossRef] [PubMed]

25. Wen, J.; Lu, L.-M.; Nie, Z.-L.; Liu, X.-Q.; Zhang, N.; Ickert-Bond, S.; Gerrath, J.; Manchester, S.R.; Boggan, J.; Chen, Z.-D. A new phylogenetic tribal classification of the grape family (Vitaceae). J. Syst. Evol. 2018, 56, 262-272. [CrossRef]

26. Soejima, A.; Wen, J. Phylogenetic analysis of the grape family (Vitaceae) based on three chloroplast markers. Am. J. Bot. 2006, 93, 278-287. [CrossRef]

27. Nie, Z.-L.; Sun, H.; Manchester, S.R.; Meng, Y.; Luke, Q.; Wen, J. Evolution of the intercontinental disjunctions in six continents in the Ampelopsis clade of the grape family (Vitaceae). BMC Evol. Biol. 2012, 12, 17. [CrossRef]

28. De Sousa, F.; Figueiredo, E.; Smith, G.F. The genus Cyphostemma (Planch.) Alston (Vitaceae) in Angola. Bradleya 2011, 29 , 79-92. [CrossRef]

29. Najmaddin, C. Comparative study on the anatomy and palynology of the three variety of Vitis vinifera varity (family Vitaceae). Afr. J. Biotechnol. 2011, 10, 16866. [CrossRef]

30. Chen, I.; Manchester, S.R. Seed morphology of modern and fossilAmpelocissus(Vitaceae) and implications for phytogeography. Am. J. Bot. 2007, 94, 1534-1553. [CrossRef] [PubMed]

31. Van Wyk, B.; van Wyk, P. Field Guide to Trees of Southern Africa; Struik: Cape Town, South Africa, 1997; p. 392.

32. Trias-Blasi, A.; Parnell, J.A.N.; Hodkinson, T.R. Multi-gene Region Phylogenetic Analysis of the Grape Family (Vitaceae). Syst. Bot. 2012, 37, 941-950. [CrossRef]

33. Retief, E. Vitaceae: A new species of Rhoicissus from the Transvaal. Bothalia 1993, 23, 232-233. [CrossRef]

34. Gerrath, J.M.; Wilson, T.; Posluszny, U. Morphological and anatomical development in the Vitaceae. VII. Floral development in Rhoicissus digitata with respect to other genera in the family. Can. J. Bot. 2004, 82, 198-206. [CrossRef]

35. Mlambo, L.; Koorbanally, N.; Moodley, R. Elemental composition of the fruits of baboon grape (Rhoicissus digitata) and im-pact of soil quality on chemical characteristics. J. Food Nutr. Res. 2016, 4, 6-11. [CrossRef]

36. Kunene, S.F. A systematic Study of the Genus RHOICISSUS Planch. (Vitacea) in Kwazulu Natal. Master's Thesis, School of life Sciences, College of Agriculture, Engineering and Science, University of KwaZulu-Natal, Durban, South Africa, 2015.

37. Teppner, H. Vitaceae in the botanic garden of the institute of botany in Graz (Austria, Europe). Fritschiana 2003, 39, 23-40.

38. Katsoulis, L. Rhoicissus tridentata subsp. Cuneifolia: The effect of geographical distribution plant storage on rat uterine contractile activity. S. Afr. J. Bot. 1999, 65, 299-302. [CrossRef]

39. Van Wyk, B.E.; Gericke, N. People's Plants: A Guide to Useful Plants of Southern Africa; Briza Publications: Pretoria, South Africa, 2000; Volume 54, p. 190.

40. McGaw, L.; Eloff, J. Ethnoveterinary use of southern African plants and scientific evaluation of their medicinal properties. $J$. Ethnopharmacol. 2008, 119, 559-574. [CrossRef]

41. Cocks, M.L.; Dold, A.P. Cultural significance of biodiversity: The role of medicinal plants in urban african cultural practices in the eastern cape, south africa. J. Ethnobiol. 2006, 26, 60-81. [CrossRef]

42. Corrigan, B.; van Wyk, B.-E.; Geldenhuys, C.; Jardine, J. Ethnobotanical plant uses in the KwaNibela Peninsula, St Lucia, South Africa. S. Afr. J. Bot. 2011, 77, 346-359. [CrossRef]

43. Philander, L.A. An ethnobotany of Western Cape Rasta bush medicine. J. Ethnopharmacol. 2011, 138, 578-594. [CrossRef] [PubMed]

44. Mshengu, B.; Uwumubyeyi, V.; Moodley, R. Chemical constituents from Rhoicissus digitata and Rhoicissus tomentosa and their chemotaxonomic significance. S. Afr. J. Bot. 2020, 135, 87-91. [CrossRef]

45. Masika, P.; Afolayan, A. An Ethnobotanical Study of Plants Used for the Treatment of Livestock Diseases in the Eastern Cape Province, South Africa. Pharm. Biol. 2003, 41, 16-21. [CrossRef]

46. Uche-okereafor, N.; Ndinteh, D.; Niemann, N.; Mavumengwana, V. Phytochemical screening, GCxGC TOF-MS analysis and antibacterial properties of crude Rhoicissus tomentosa rhizome extract. In Proceedings of the International Conference on Advances in Science, Engineering, Technology and Natural Resources, Singapore, 11-12 May 2016; pp. 24-25. [CrossRef] 
47. Arwa, P.; Onyango, J.; Nyuja, R. Phytochemical compounds and antimicrobial activity of extracts of Rhoicissus plant (Rhoi-cissus revoilli) (Planch). Plant Sci. Res. 2008, 1, 68-73.

48. Enyew, A.; Asfaw, Z.; Kelbessa, E.; Nagappan, R. Ethnobotanical Study of Traditional Medicinal Plants in and Around Fiche District, Central Ethiopia. Curr. Res. J. Biol. Sci. 2014, 6, 154-167. [CrossRef]

49. Varga, C.; Veale, D. Isihlambezo: Utilization patterns and potential health effects of pregnancy-related traditional herbal medicine. Soc. Sci. Med. 1997, 44, 911-924. [CrossRef]

50. Brookes, K.B.; Smith, A.N. Cytotoxicity of pregnancy-related traditional medicines. S. Afr. Med. J. 2003, 93, 359-361. [PubMed]

51. Katsoulis, L.C.; Veale, D.J.H.; Havlik, I. Seasonal variation in uterotonic activity of Rhoicissus tridentata extracts. S. Afr. Med. J. 2002, 92, 375-377.

52. Mamba, P.; Adebayo, S.A.; Tshikalange, T.E. Anti-microbial, anti-inflammatory and HIV-1 reverse transcriptase activity of selected South African plants used to treat sexually transmitted diseases. Int. J. Pharmacogn. Phytochem. Res. 2016, 8, $1870-1876$.

53. Opoku, A.; Ndlovu, I.; Terblanche, S.; Hutchings, A. In vivo hepatoprotective effects of Rhoicissus tridentata subsp. cuneifolia, a traditional Zulu medicinal plant, against CCl4-induced acute liver injury in rats. S. Afr. J. Bot. 2007, 73, 372-377. [CrossRef]

54. Tuwange, I.; Olila, D. The anthelmintic activity of selected indigenous medicinal plants used by the Banyakole of western Uganda. J. Anim. Vet. Adv. 2006, 5, 712-717.

55. Naidoo, V.; Chikoto, H.; Bekker, L.; Eloff, J. Antioxidant compounds in Rhoicissus tridentata extracts may explain their antibabesial activity: Research in action. S. Afr. J. Sci. 2006, 102, 198-200.

56. Rakuambo, N.; Meyer, J.; Hussein, A.; Huyser, C.; Mdlalose, S.; Raidani, T. In vitro effect of medicinal plants used to treat erectile dysfunction on smooth muscle relaxation and human sperm. J. Ethnopharmacol. 2006, 105, 84-88. [CrossRef]

57. Some, G.K.F.; Kigen, G.; Some, F.; Kibosia, J.; Rono, H.; Kiprop, E.; Wanjohi, B.; Kigen, P.; Kipkore, W. Ethnomedicinal Plants Traditionally Used by the Keiyo Community in Elgeyo Marakwet County, Kenya. J. Biodivers. Bioprospecting Dev. 2014, 1, 1-11. [CrossRef]

58. Van der Merwe, D.; Swan, G.; Botha, C. Use of ethnoveterinary medicinal plants in cattle by Setswana-speaking people in the Madikwe area of the North West Province of South Africa. J. S. Afr. Vet. Assoc. 2001, 72, 189-196. [CrossRef]

59. Lin, J.; Opoku, A.; Geheeb-Keller, M.; Hutchings, A.; Terblanche, S.; Jäger, A.K.; van Staden, J. Preliminary screening of some traditional zulu medicinal plants for anti-inflammatory and anti-microbial activities. J. Ethnopharmacol. 1999, 68, 267-274. [CrossRef]

60. Agyare, C.; Obiri, D.D.; Boakye, Y.D.; Osafo, N. Anti-Inflammatory and Analgesic Activities of African Medicinal Plants. Med. Plant Res. Afr. 2013, 725-752. [CrossRef]

61. Samie, A.; Obi, C.L.; Bessong, P.O.; Namrita, L. Activity profiles of fourteen selected medicinal plants from Rural Venda communities in South Africa against fifteen clinical bacterial species. Afr. J. Biotechnol. 2005, 4, 1443-1451. [CrossRef]

62. Magak, S.K.; Njoroge, G.N. Self-reported Hand Hygiene Practices among Traditional Health Care Workers (Herbalists) In Bungoma, Kenya. Trop. Med. Health 2010, 38, 133-137. [CrossRef]

63. Maima, A.O.; Ndwigah, S.N.; Thoithi, G.N.; Kamau, F.N.; Kibwage, I.O. Antimicrobial properties of some medicinal plants of the Luo community of Kenya. Afr. J. Pharmacol. Ther. 2014, 3, 112-115.

64. Samie, A.; Mashau, F. Antifungal activities of fifteen southern African medicinal plants against five Fusarium species. J. Med. Plant Res. 2013, 7, 1839-1848. [CrossRef]

65. Tshikalange, T.E.; Mamba, P.; Adebayo, S.A. Antimicrobial, antioxidant and cytotoxicity studies of medicinal plants used in the treatment of sexually transmitted diseases. Int. J. Pharmacogn. Phytochem. Res. 2016, 8, 1891-1895.

66. Baloyi, I.; Cosa, S.; Combrinck, S.; Leonard, C.; Viljoen, A. Anti-quorum sensing and antimicrobial activities of South African medicinal plants against uropathogens. S. Afr. J. Bot. 2019, 122, 484-491. [CrossRef]

67. Opoku, A.R.; Maseko, N.F.; Terblanche, S.E. The in vitro antioxidative activity of some traditional Zulu medicinal plants. Phytother. Res. 2002, 16, 51-56. [CrossRef] [PubMed]

68. Katsoulis, L.C.; Veale, D.J.H.; Havlik, I. The pharmacological action ofRhoicissus tridentata on isolated rat uterus and ileum. Phytother. Res. 2000, 14, 460-462. [CrossRef]

69. Nalule, A.S.; Mbaria, J.M.; Kimenju, J.W.; Olila, D. Ascaricidal activity of Rhoicissus tridentata root-tuber ethanolic and water extracts. Livest. Res. Rural. Dev. 2012, 24. Available online: http://www.lrrd.org//nalu24144.htm (accessed on 3 October 2020).

70. Karmali, M.A.; Roscoe, M.; Fleming, P.C. Modified ammonia electrode method to investigate D-asparagine breakdown by Campylobacter strains. J. Clin. Microbiol. 1986, 23, 743-747. [CrossRef] [PubMed]

71. Gad, M.Z. Anti-aging effects of 1-arginine. J. Adv. Res. 2010, 1, 169-177. [CrossRef]

72. Buschmann, H.-J.; Schollmeyer, E.; Mutihac, L. The formation of amino acid and dipeptide complexes with $\alpha$-cyclodextrin and cucurbit[6] uril in aqueous solutions studied by titration calorimetry. Thermochim. Acta 2003, 399, 203-208. [CrossRef]

73. Dobolyi, A.; Juhász, G.; Kovacs, Z.; Kardos, J. Uridine function in the central nervous system. Curr. Top. Med. Chem. 2011, 11, 1058-1067. [CrossRef] [PubMed]

74. Jadhav, V.; Kalase, V.; Patil, P. GC-MS analysis of bioactive compounds in methanolic extract of Holigarna grahamii (wight) Kurz. Int. J. Herb. Med. 2014, 2, 35-39.

75. Keawsa-Ard, S.; Liawruangrath, B.; Liawruangrath, S.; Teerawutgulrag, A.; Pyne, S.G. Chemical Constituents and Antioxidant and Biological Activities of the Essential Oil from Leaves of Solanum spirale. Nat. Prod. Commun. 2012, 7, 955-958. [CrossRef] 
76. Donia, M.; Hamann, M.T. Marine natural products and their potential applications as anti-infective agents. Lancet Infect. Dis. 2003, 3, 338-348. [CrossRef]

77. Brash, A.R. Arachidonic acid as a bioactive molecule. J. Clin. Investig. 2001, 107, 1339-1345. [CrossRef] [PubMed]

78. Hussain, I. Fatty acid composition of Boerhaavia procumbens L. roots oil by gas chromatography mass spectrometry. J. Med. Plants Res. 2012, 6, 2789-2792. [CrossRef]

79. Ajoku, G.A.; Okwute, S.K.; Okogun, J.I. Isolation of Hexadecanoic Acid Methyl Ester and 1,1,2-Ethanetricarboxylic Acid1-Hydroxy-1, 1-Dimethyl Ester from the Calyx of Green Hibiscus Sabdariffa (Linn). Nat. Prod. Chem. Res. 2015, 3, 169. [CrossRef]

80. Asghari, G.; Jalali, M.; Sadoughi, E. Antimicrobial activity and chemical composition of essential oil from the seeds of Artemi-sia aucheri Boiss. Jundishapur J. Nat. Pharm. Prod. 2012, 7, 11-15. [CrossRef]

81. Waterman, E.; Lockwood, B. Active components and clinical applications of olive oil: A review. Altern. Med. Rev. 2007, 12, 331-342.

82. Li, X.-C.; Jacob, M.R.; Khan, S.I.; Ashfaq, M.K.; Babu, K.S.; Agarwal, A.K.; ElSohly, H.N.; Manly, S.P.; Clark, A.M. Potent In Vitro Antifungal Activities of Naturally Occurring Acetylenic Acids. Antimicrob. Agents Chemother. 2008, 52, 2442-2448. [CrossRef]

83. Nqolo, N.L. Phytochemical Study of Rhoicissus Tomentosa. Master's Thesis, Department of Chemistry, University of Western Cape, Cape Town, South Africa, 2008.

84. Wal, A.; Rai, A.; Wal, P.; Sharma, G. Biological activities of lupeol. Syst. Rev. Pharm. 2011, 2, 96. [CrossRef]

85. Saeidnia, S.; Manayi, A.; Gohari, A.R.; Abdollahi, M. The story of $\beta$-sitosterol. Eur. J. Med. Chem. 2014, 4, 590-609.

86. Lin, C.; Wen, X.; Sun, H. Oleanolic acid derivatives for pharmaceutical use: A patent review. Expert Opin. Ther. Patents 2016, 26, 643-655. [CrossRef]

87. Gramza, A.; Korczak, J.; Amarowicz, R. Tea polyphenols-their antioxidant properties and biological activity-A review. Pol. J. Food Nutr. Sci. 2005, 14, 219.

88. Wang, W.; Sun, C.; Mao, L.; Ma, P.; Liu, F.; Yang, J.; Gao, Y. The biological activities, chemical stability, metabolism and delivery systems of quercetin: A review. Trends Food Sci. Technol. 2016, 56, 21-38. [CrossRef]

89. Khanra, R.; Bhattacharjee, N.; Dua, T.K.; Nandy, A.; Saha, A.; Kalita, J.; Manna, P.; Dewanjee, S. Taraxerol, a pentacyclic triterpenoid, from Abroma augusta leaf attenuates diabetic nephropathy in type 2 diabetic rats. Biomed. Pharmacother. 2017, 94, 726-741. [CrossRef]

90. Kaur, N.; Chaudhary, J.; Jain, A.; Kishore, L. Stigmasterol: A comprehensive review. Int. J. Pharm. Sci. Res. 2011,2 , 2259.

91. Pangestuti, R.; Kim, S.-K. Biological activities and health benefit effects of natural pigments derived from marine algae. J. Funct. Foods 2011, 3, 255-266. [CrossRef]

92. Fuad, N.I.N.; Sekar, M.; Gan, S.H.; Lum, P.T.; Vaijanathappa, J.; Ravi, S. Lutein: A Comprehensive Review on its Chemical, Biological Activities and Therapeutic Potentials. Pharmacogn. J. 2020, 12, 1769-1778. [CrossRef]

93. Kim, E.M.; Jung, H.R.; Min, T.J. Purification, structure determination and biological activities of 20(29)-lupen-3-one from Daedaleopsis tricolor. Bull. Korean Chem. Soc. 2001, 22, 59.

94. Loggia, R.; Tubaro, A.; Sosa, S.; Becker, H.; Saar, S.; Isaac, O. The Role of Triterpenoids in the Topical Anti-Inflammatory Activity ofCalendula officinalisFlowers. Planta Med. 1994, 60, 516-520. [CrossRef] [PubMed] 